\title{
ECONOMIC DEVELOPMENT STRATEGY
}

UDC 629.735.067:629.735-005.44(043.2)

\section{Mykola Kulyk ${ }^{1}$ \\ Dmytro Bugayko ${ }^{2}$ Oksana Ilienko ${ }^{3}$}

\section{SAFETY OF AVIATION IN GLOBAL CONTEXT OF THE WORLD AIR TRANSPORT DEVELOPMENT}

\author{
National Aviation University \\ Kosmonavta Komarova avenue 1, 03680, Kyiv, Ukraine \\ E-mails: ${ }^{1}$ kulyk@nau.edu.ua; ${ }^{2}$ bugaiko@nau.edu.ua; ${ }^{3}$ oks-ilenko1@yandex.ru
}

\begin{abstract}
Increasing of civil aviation safety level is one of principal objectives of world air transport development. Present research paper discusses modern trends of civil aviation activity. Special attention is paid to efficiency, safety and security of the global air transport system.
\end{abstract}

Keywords: aviation safety; effectiveness; efficiency; forecasts; safety of aviation; security.

\section{Introduction}

The air transport industry plays a major role in world economic activity. One of the key elements to maintaining the vitality of civil aviation is to ensure safe, secure, efficient and environmentally sustainable operations at the global, regional and national levels. A specialized agency of the United Nations, the International Civil Aviation Organization (ICAO) was created in 1944 to promote the safe and orderly development of international civil aviation throughout the world. ICAO sets the Standards and Recommended Practices (SARPs) necessary for aviation safety, security, efficiency and environmental protection on a global basis. ICAO serves as the primary forum for cooperation in all fields of civil aviation among its 191 Member States [ICAO...2013].

In connection with the principal importance of safety of aviation for the development of global air transport, theme of paper is especially relevance.

\section{Aviation Safety - Core of ICAO's Fundamental Objectives}

Aviation safety is at the core of ICAO's fundamental objectives. The organization is constantly striving, in close collaboration with the entire air transport community, to further improve aviation's successful safety performance while maintaining a high level of efficiency. This is achieved through:

1. The development of global strategies contained in the Global Aviation Safety Plan and the Global Air Navigation Plan;

2. The development and maintenance of Standards, Recommended Practices and Procedures applicable to international civil aviation activities which are contained in Annexes and PANS (Procedures for Air Navigation Services). These standards are complemented by more than 50 Manuals and Circulars which are providing guidance on their implementation;

3. The monitoring of safety trends and indicators. ICAO audits the implementation of its Standard, Recommended Practices and Procedures through its Universal Safety Oversight Audit Programme. It has also developed sophisticated tools to collects and analyse a vast array of safety data which allows to identify existing and emerging risks;

4. The implementation of targeted safety programmes to address safety and infrastructure deficiencies;

5. An effective response to disruption of the aviation system created by natural disasters, conflicts or other causes [ICAO...1997].

In all of its highly coordinated safety activities, ICAO strives to implement practical and achievable measures to improve safety and efficiency in all sectors of the air transportation system. This approach ensures that aviation's complimentary achievements of a remarkably safe and efficient air transport network continue to serve a fundamental role in supporting global social and economic priorities.

Cooperation is a consistent goal and recognized strength of the aviation community. To keep pace with expansion and progress sector wide, ICAO remains focused on the implementation and development of new safety initiatives. The Runway Safety Programme and Fatigue Risk Management 
Systems are examples of how ICAO is working with stakeholders to identify hazards and manage risk. ICAO is committed to improving aviation safety and enabling seamless cooperation and communication between stakeholders [Safety...].

ICAO continues to collaborate with established regional organizations, such as Regional Aviation Safety Groups (RASGs) and Regional Safety Oversight Organizations (RSOOs), and to promote the training and support necessary to address emerging safety issues. In addition, ICAO continues to actively engage with other agencies of the United Nations - including the World Meteorological Organization in preparing for and responding to natural hazards such as volcanic eruptions that impact global air navigation safety and efficiency. Fig. 1 presents the ICAO Accidents Records 2006-2012 (Scheduled commercial flights) [ICAO...2013].

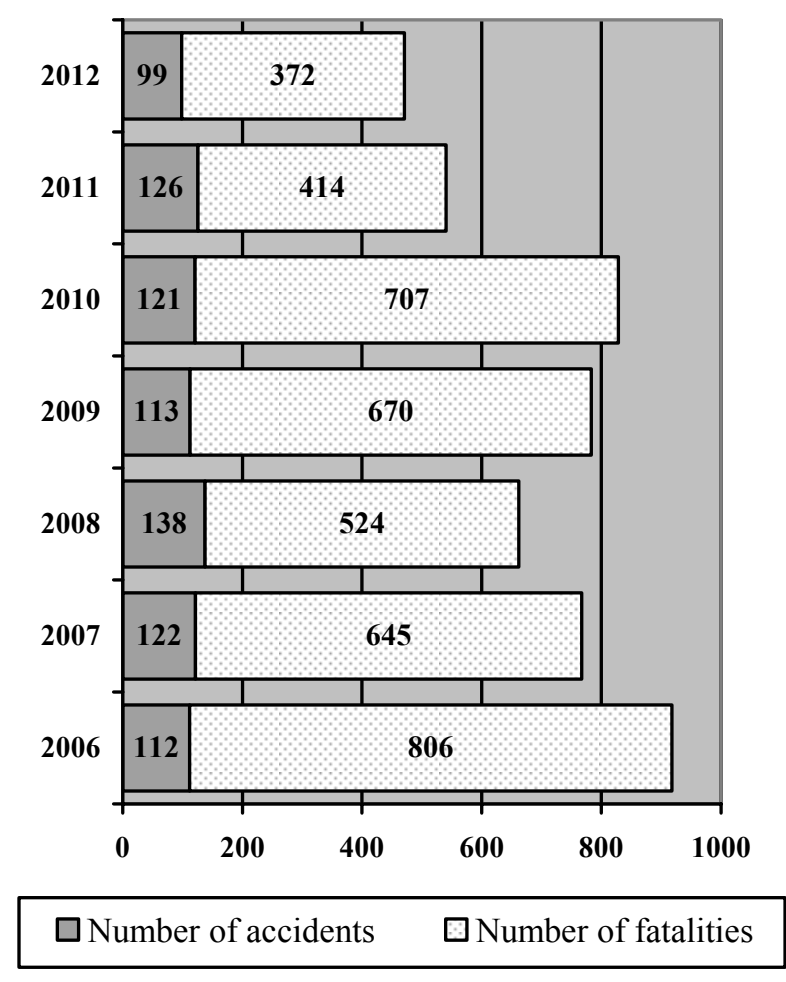

Fig. 1. ICAO Accidents Records 2006-2012

(Scheduled commercial flights)

\section{Forecasts of Air Transport Development}

However, unfortunately, the dynamic reduction in the total number of accidents is not possible to eliminate the need for a permanent safety level increasing. Forecasts of the leading organizations in the field of civil aviation and aircraft manufacturers suggest an expected substantial increase in the number of flights of civil aviation.
Regarding ICAO Outlook for air transport to the year 2025, world economic growth (GDP) is expected to increase at an average annual rate of 3.5 per cent in real terms. Airline yields are expected to remain unchanged in real terms for the forecast horizon. World scheduled traffic measured in terms of PKPs is forecast to increase at a "most likely" average annual rate of 4.6 per cent for the period 2005-2025. International traffic is expected to increase at 5.3 per cent per annum, while domestic traffic is expected to increase at an average annual rate of 3.4 per cent (Table 1) [Eurocontrol...].

Forecasts developed by the Airport Council International (ACI) for the period 2006-2025 indicate average annual growth rates of 4 per cent and 5.4 per cent in the total number of passengers and freight tonnes, respectively [Outlook...].

EUROCONTROL middle term forecast - a result of the current poor economic outlook, which is for stagnation or weak growth, and the current traffic situation. Over the remaining years of the forecast, flight growth is stronger at around 3\% per year. This, however, reflects a long-term growth trend that is forecast to be lower than in the past.Total traffic reaches 11.3 Million flights in 2018 (Table 2) [Eurocontrol...].

Some recent long-term forecasts by major airframe and engine manufacturers of growth in world scheduled traffic are given in Table 3. These forecast growth rates are in the range of 4.8 to 5.0 per cent per annum for passenger-kilometers, with freight tonne - kilometers generally forecast to grow at a slightly higher rate for the period ranging from 2005 to 2026 .

Boeing long term forecast - Commercial aviation has weathered many downturns in the past. Yet recovery has followed quickly as the industry reliably returned to its long-term growth rate of approximately 5 percent per year. Despite uncertainties, 2012 passenger traffic rose 5.3 percent from 2011 levels. Boeing experts expect this trend to continue over the next 20 years, with world passenger traffic growing 5.0 percent annually. Air cargo traffic has been moderating after a high period in 2010. Air cargo contracted by 1.5 percent in 2012. Expansion of emerging-market economies will, however, foster a growing need for fast, efficient transport of goods. Experts estimate that air cargo will grow 5.0 percent annually through 2032 [Current...2013]. Experts of Airbus predict a similar trends. In their view, 20-year world annual traffic growth will be $4,7 \%$ [Airbus... 2012]. 
Table 1. ICAO Air Traffic Forecasts — World: ICAO Contracting States (1985-2025)

\begin{tabular}{|c|c|c|c|c|c|}
\hline \multirow{2}{*}{ Scheduled services } & \multirow{2}{*}{$\begin{array}{c}\text { Actual } \\
1985\end{array}$} & \multirow{2}{*}{$\begin{array}{c}\text { Actual } \\
2005\end{array}$} & \multirow{2}{*}{$\begin{array}{c}\text { Forecast } \\
2025\end{array}$} & \multicolumn{2}{|c|}{$\begin{array}{l}\text { Average annual } \\
\text { growth } \\
\text { rate (per cent) }\end{array}$} \\
\hline & & & & $\begin{array}{l}1985- \\
2005\end{array}$ & $\begin{array}{l}2005- \\
2025\end{array}$ \\
\hline \multicolumn{6}{|l|}{ TOTAL } \\
\hline Passenger-kilometres (billions) & 1366 & 3720 & 9180 & 5,1 & 4,6 \\
\hline Freight tonne-kilometres (millions) & 39813 & 142579 & 810000 & 6,6 & 6,6 \\
\hline Passengers carried (millions) & 896 & 2022 & 4500 & 4,2 & 4,1 \\
\hline Freight tonnes carried (thousands) & 13742 & 37660 & 145000 & 5,2 & 5,5 \\
\hline Aircraft-kilometres (millions) & n.a. & 30845 & 69040 & n.a. & 4.1 \\
\hline Aircraft departures (thousands) & n.a. & 24904 & 50450 & n.a. & 3,6 \\
\hline \multicolumn{6}{|l|}{ INTERNATIONAL } \\
\hline Passenger-kilometres (billions) & 589 & 2197 & 6225 & 6,8 & 5,3 \\
\hline Freight tonne-kilometres (millions) & 29384 & 118482 & 452120 & 7,2 & 6,9 \\
\hline Passengers carried (millions) & 194 & 704 & 1950 & 6,7 & 5,2 \\
\hline Freight tonnes carried (thousands) & 5884 & 22630 & 110000 & 7,0 & 6,5 \\
\hline
\end{tabular}

Table 2. Summary of the Forecast for Europe (ESRA08)

\begin{tabular}{|c|c|c|c|c|c|c|c|c|c|c|c|c|c|c|c|}
\hline $\begin{array}{c}\text { Types of } \\
\text { Traffic Data } \\
\text { and } \\
\text { Forecasts }\end{array}$ & 2006 & 2007 & 2008 & 2009 & 2010 & 2011 & 2012 & 2013 & 2014 & 2015 & 2016 & 2017 & 2018 & $\begin{array}{c}\text { AAGR } \\
2018 \\
/ 2011\end{array}$ \\
\hline $\begin{array}{c}\text { IFR } \\
\text { Movements } \\
\text { (thousand) }\end{array}$ & $\mathrm{H}$ & - & - & - & - & - & - & 9,759 & 9,999 & 10,414 & 10,805 & 11,229 & 11963 & 12057 & $3,0 \%$ \\
\cline { 2 - 13 } & $\mathrm{L}$ & - & - & - & - & - & - & 9,565 & 9,626 & 9,778 & 9,968 & 10,182 & 10,365 & 10,560 & $1,1 \%$ \\
\hline $\begin{array}{c}\text { Annual } \\
\text { Growth } \\
\left(\begin{array}{c}\text { compared } \\
\text { to previous } \\
\text { year) }\end{array}\right.\end{array}$ & $\mathrm{B}$ & - & - & - & - & - & - & $-0,3$ & $2,5 \%$ & $4,1 \%$ & $3,8 \%$ & $3,9 \%$ & $4,1 \%$ & $3,1 \%$ & $3,0 \%$ \\
\cline { 2 - 13 } & $\mathrm{L}$ & - & - & - & - & - & - & $-2,2$ & $0,6 \%$ & $1,6 \%$ & $1,9 \%$ & $2,2 \%$ & $1,8 \%$ & $1,9 \%$ & $1,1 \%$ \\
\hline
\end{tabular}

Table 3. Global Scheduled Traffic Forecasts by Aerospace Manufacturers for the Period 2006-2025

\begin{tabular}{|l|c|c|c|}
\hline \multirow{2}{*}{ Aerospace manufacturer } & \multirow{2}{*}{ Forecast period } & \multicolumn{2}{c|}{ Average annual growth rate (per cent) } \\
\cline { 3 - 4 } & & Passenger - kilometers & Freight tonne - kilometers \\
\hline Airbus Industrie & $2006-2025$ & 4,8 & 6.0 \\
\hline Boeing & $2005-2025$ & 4,8 & - \\
\hline Embraer & $2007-2026$ & 5,0 & - \\
\hline Rolls-Royce & $2006-2025$ & 4,8 & 6,8 \\
\hline
\end{tabular}




\section{ICAO ATM Global System Safety Approach}

Safety will remain the highest priority in aviation, and the safety of air traffic will continue to be the most important consideration in all phases of the life cycle of the ATM system, from concept through to design, development, operation and maintenance. The system safety approach outlined below is holistic, applying across the spectrum of the ATM system, where the system will be considered to include people, procedures and technologies performing specific tasks in a given environment. Maximum effectiveness and efficiency of actions can be obtained by activities undertaken in the early phases of any system's life cycle since correcting problems during requirements definition and design is generally the most effective [ICAO...2005].

The acceptable or tolerable level of safety will be determined from the perception of safety needs by society and the international community. Acceptable safety will be related to the trust required from the ATM system. The target level of safety will be the minimum level of safety to be achieved in any case. Possibly enforced by regulation, it will be equal to or better than the acceptable level of safety. The target level of safety will be based on risk assessment and acceptance criteria. results in a defined range without compromising acceptable and target levels of safety. These levels of safety could be specified in qualitative and/or quantitative terms, often, but not exclusively, via indicators related to safety occurrences. Examples of the latter include:

- a maximum probability of an undesirable event such as collision, loss of separation or

- runway incursion; hour;

- a maximum number of accidents per flight

- a maximum number of incidents per aircraft movement;

- a maximum number of valid short-term conflict alerts per aircraft movement [Bugayko 2012].

\section{Modern Trends of Aviation Security}

Security is a second strategic target of worldwide aviation activity development. The main problem is the dynamical growth of global aviation system and increasing of number of passengers, cargo shippers and consignees, which involved in the aviation transportation. At present, we can identify the following areas of security for world air transportation system:
- Physical security - aircraft protection; passenger and cargo security check; tampering; access control to air transport system infrastructure.

- Cyber security - protection of software and data links from hacking; spoofing; interference or malicious hijack.

Declaration on Aviation Security of 37th ICAO Assembly hereby urges Member States to take the following actions to enhance international cooperation to counter threats to civil aviation [37th ICAO...]:

- strengthen and promote the effective application of ICAO Standards and Recommended Practices, with particular focus on Annex 17 Security, and develop strategies to address current and emerging threats;

- strengthen security screening procedures, enhance human factors and utilize modern technologies to detect prohibited articles and support research and development of technology for the detection of explosives, weapons and prohibited articles in order to prevent acts of unlawful interference;

- develop enhanced security measures to protect airport facilities and improve in-flight security, with appropriate enhancements in technology and training;

- develop and implement strengthened and harmonized measures and best practices for air cargo security, taking into account the need to protect the entire air cargo supply chain;

- promote enhanced travel document security and the validation thereof using the ICAO Public Key Directory (PKD) in conjunction with biometric information, and the commitment to report on a regular basis, lost and stolen passports to the INTERPOL Lost and Stolen Travel Documents Database to prevent the use of such travel documents for acts of unlawful interference against civil aviation;

- improve Member States' ability to correct deficiencies identified under the Universal Security Audit Programme (USAP) by ensuring the appropriate availability of audit results among Member States, which would enable better targeting of capacity-building and technical assistance efforts;

- provide technical assistance to States in need, including funding, capacity building and technology transfer to effectively address security threats to civil aviation, in cooperation with other States, international organizations and industry partners; 
- promote the increased use of cooperation mechanisms among Member States and with the civil aviation industry, for information exchange on security measures in order to avoid redundancy, where appropriate, and for early detection and dissemination of information on security threats to civil aviation, including through the collection and transmission of advance passenger information (API) and passenger name record (PNR) data, as an aid to security, whilst ensuring the protection of passengers' privacy and civil liberties; and

- share best practices and information in a range of key areas, such as: screening and inspection techniques, including assessments of advanced screening technology for the detection of weapons and explosives; document security and fraud detection; behavior detection and threat-based risk analysis; screening of airport employees; the privacy and dignity of persons; and aircraft security.

\section{Conclusions}

The globalization of international air transport includes many aspects and play important role in process of world civil aviation development.

Among the positive aspects of globalization is possible to determine improvement of global civil aviation safety system, which unites leading international and regional, intergovernmental and non-governmental organizations in order to improve safety, security, efficiency and economic feasibility of aviation activities.

Forecasts of the leading organizations in the field of civil aviation and aircraft manufacturers point to the growth of global air transportation traffic.
These trends make it necessary to continuously increase level of safety, security and efficiency of aviation system. The complex issue of world aviation system safety, security and efficiency aspects is the basis for their future development.

\section{References}

Airbus Global Market Forecast 2012-2031. Airbus 2012.

Bugayko, D. 2012. Safety and Effectiveness of Civil Aviation in Conditions of Air Traffic Globalization. Proceedings the fifth World Congress "Aviation in the XXI-st century". "Safety in Aviation and Space Technologies", 25-27 sept. 2012. Kyiv, National Avaition University. Vol. 2: 3.1.26-3.1.28.

Current Market Outlook 2013-2032. Boeing Commercial Airplanes, Seattle, 2013.

Eurocontrol flight movement forecasts to 2019. Available from Internet: <http://centreforaviation. com/analysis/eurocontrol-flight-movement-forecasts -to-2019-go-east-young-man-100117>

ICAO Global Air Traffic Management Operational Concept (Doc 9854). Montreal: Canada (ICAO), 2005.

ICAO Global Aviation Safety Plan 1997. ICAO. ICAO Safety Report 2013. ICAO.

Outlook for Air Transport to the Year 2025. ICAO, CIR 313/ AT 134.

Safety Management Manual (SMM). ICAO, Doc 9859 AN/460.

37th ICAO Assembly - Declaration on Aviation Security. Available from Internet: $<$ http://www.icao. int/Security/Documents/Bahrain/ICAO\%20Declarati on $\% 20$ on $\% 20$ Aviation\%20Security.pdf $>$

Received 16 September 2013.

\section{М.С. Кулик ${ }^{1}$, Д.О. Бугайко ${ }^{2}$, О.В. Ільєнко ${ }^{3}$. Безпека авіації у глобальному контексті розвитку світового авіаційного транспорту}

Національний авіаційний університет, просп. Космонавта Комарова 1, Київ, Україна, 03680

E-mails: ${ }^{1}$ kulyk@nau.edu.ua; ${ }^{2}$ bugaiko@nau.edu.ua; ${ }^{3}$ oks-ilenko1@yandex.ru

Показано, що підвищення рівня безпеки цивільної авіації $є$ однією з основних цілей розвитку світового повітряного транспорту. Досліджено сучасні тенденції діяльності цивільної авіації. Проаналізовано базові принципи регулювання питань безпеки авіації з боку міжнародних та регіональних організацій в галузі цивільної авіації. Особливу увагу приділено стандартам та рекомендованій практиці Міжнародної організації цивільної авіації в галузі безпеки. Наведено статистику авіаційних катастроф. Розглянуто довго- та середньострокові прогнози розвитку авіаційної галузі цивільної авіації, підготовлені Міжнародною організацією цивільної авіації, Міжнародною радою аеропортів, Свропейським агентством із забезпечення безпеки аеронавігації, виробниками авіаційної техніки Boeing та Airbus. Зазначено особливості забезпечення безпеки світової системи управління повітряним рухом. Ідентифіковано галузі авіаційної безпеки світової системи повітряного транспорту. Визначено ефективність безпеки польотів та авіаційної безпеки глобальної системи повітряного транспорту.

Ключові слова: авіаційна безпека; безпека авіації; безпека польотів; ефективність; прогнози. 
Н.С. Кулик ${ }^{1}$, Д.А. Бугайко ${ }^{2}$, О.В. Ильенко ${ }^{3}$ Безопасность авиации в глобальном контексте развития мирового авиационного транспорта

Национальный авиационный университет, просп. Космонавта Комарова 1, Киев, Украина, 03680

E-mails: ${ }^{1}$ kulyk@nau.edu.ua; ${ }^{2}$ bugaiko@nau.edu.ua; ${ }^{3}$ oks-ilenko1@yandex.ru

Показано, что повышение уровня безопасности гражданской авиации является одной из основных целей развития мирового воздушного транспорта. Исследованы современные тенденции деятельности гражданской авиации. Проанализированы базовые принципы регулирования вопросов безопасности авиации со стороны международных и региональных организаций в области гражданской авиации. Особое внимание уделено стандартам и рекомендованной практике Международной организации гражданской авиации в области безопасности. Приведена статистика авиационных катастроф. Рассмотрены долго- и среднесрочные прогнозы развития авиационной отрасли гражданской авиации, подготовленные Международной организацией гражданской авиации, Международным советом аэропортов, Европейским агентством по обеспечению безопасности аэронавигации, производителями авиационной техники Boeing и Airbus. Указаны особенности обеспечения безопасности мировой системы управления воздушным движением. Идентифицированы области авиационной безопасности мировой системы воздушного транспорта. Определена эффективность безопасности полетов и авиационной безопасности глобальной системы воздушного транспорта.

Ключевые слова: авиационная безопасность; безопасность авиации; безопасность полетов; прогнозы; эффективность.

Kulyk Mykola (1952). Doctor of Engineering. Professor. Holder of a State Award in Science and Engineering of Ukraine (2003). Winner of a State Prize of Ukraine in Science and Engineering (2005).

Rector of the National Aviation University, Kyiv, Ukraine.

Head of the Department of Aircraft Engines, National Aviation University, Kyiv, Ukraine.

Education: Kyiv Institute of Civil Aviation, Kyiv, Ukraine (1978).

Research area: definition of the technical state of aircraft engines.

Publications: over 200.

E-mail:kulyk@nau.edu.ua

Bugayko Dmytro (1973). Leading Researcher. National Aviation University, Kyiv, Ukraine.

Education: Faculty of Organization of Aviation Works and Transportations, Kyiv International University of Civil Aviation, Kyiv, Ukraine (1995).

Research area: economic progress of civil aviation trends in the conditions of globalization of transport services market. Publications: 58 .

E-mail: bugaiko@nau.edu.ua

Ilienko Oksana (1974). Associate Professor.

Logistics Departmen, National Aviation University, Kyiv, Ukraine.

Dean of Faculty of Management and Logistics, National Aviation University, Kyiv, Ukraine.

Education: Kyiv Institute of the Ukrainian State Academy of Communications name of O.S. Popova, Kyiv, Ukraine (2000).

Research area: modern logistic systems, economic security of air transport industry.

Publications: 24 .

E-mail: oks-ilenko1@yandex.ru 